\title{
Journal Competency of Business
}

\author{
2020 Vol 4. No II \\ PENGARUH SISTEM KEUANGAN DESA TERHADAP KINERJA \\ PEMERINTAH DESA DENGAN GOOD GOVERNANCE SEBAGAI \\ VARIABEL INTERVENING DI KABUPATEN KULON PROGO
}

(Studi Kasus di Kecamatan Panjatan)

Wihastinelahi*

Teguh Erawati**

Universitas Sarjanawiyata Tamansiswa

*email: Wihasti0297@gmail.com

\begin{abstract}
This research was conducted to find out the role of village financial system (Siskeudes) on the performance of village administration with good governance as an intervening variable in Kulon Progo Regency. This research employed quantitative research approach. The data used were primary data. The informants used were village Kaur and Kasi, the village secretaries, the village financial system operators (Siskeudes).

The result showed that: (1) village financial system (Siskeudes) influences on the good governance; (2) good governance influences on the performance of the village administration; (3) village financial system (Siskeudes) no effect to performance of village administration; (4) village financial system (Siskeudes) on the performance of village administration with good governance an an intervening variable.
\end{abstract}

Keywords Village Financial System (Siskeudes), Good Governance, Performance of village administration.

\section{PENDAHULUAN}

Sistem pemerintahan yang ada saat ini, desa mempunyai peranan yang sangat penting dalam membantu kegiatan pemerinathan daerah dalam proses penyelenggaraan pemerinathan termasuk kegiatan pembangunan yang berhubungan langsung dengan masyarakat. Undang-Undang Nomor 6 Tahun 2014 Pasal 1 Ayat 1 menegaskan bahwa desa adalah kesatuan masyarakat hukum yang memiliki btas wilayah yang berwenang dalam mengatur dan mengurus urusan pemerintahan, kepentingan masyarakat setempat berdasarkan prakarsa masyarakat, hal asal usul, dan hak tradisional yang diakui dan dihormati dalam sistem pemerintahan NKRI. UndangUndang desa juga memberi jaminan yang lebih pasti bahwa setiap desa akan menerima dana dari pemeintah melalui anggaran negara dan daerah yang jumlahnya berlipat jauh diatas jumlah yang selama ini tersedia dalam anggaran desa. Kebijakan ini memiliki konsekuensi terhadap proses pengelolaannya yang seharusnya 


\section{Journal Competency of Business}

\section{Vol 4. No II}

dilaksanakan secara profesional, efektif, akuntabel dan transparan yang didasarkan pada prinsip-prinsip manajemen publik yang baik agar terhindar dari risiko penyelewengan, penyimpangan dan korupsi.

Penyelenggaraan Anggaran Pendapatan dan Belanja Daerah memiliki peran penting dalam mensukseskan pembangunan daerah. APBDes dapat dijadikan cerminan kinerja dan kemampuan pemerintah desa dalam mengelola segala rencana penyelenggaraan pemerintah dan pelaksanaan pembangunan di desa. Anggaran desa yang diidstribusikan dari pusat akhir-akhir ini banyak diselewengkan oleh oknumoknum tertentu karena kurangnya pengetahuan maupun pemahaman aparat desa dalam mengelola anggaran. Sistem informasi akuntansi sangat dibutuhkan untuk mengatasi hal tersebut.

Pemerintah bersama Kementerian Dalam Negeri dan Badan Pengawasan Keuangan dan Pembangunan telah mendorong akuntabilitas pengelolaan keuangan desa dengan mengembangkan aplikasi Sistem Keuangan Desa (SISKEUDES). Aplikasi ini bertujuan untuk memudahkan dalam pelaporan keuangan dan untuk menata kelola keuangan desa secara optimal serta sebagai alat kendali/tolak ukur pengelolaan keuangan desa sehingga tidak keluar dari koridor peraturan perundangundangan.

Salah satu landasan pemerintahan yang bersih yaitu dengan menerapkan prinsipprinsip good governance. Good Governance merupakan sistem yang diterapkan oleh pemerintah demi terwujudnya pemerintahan yang efektif dan efisien, sehat dan bermutu, serta memberikan dampak yang baik bagi pemerintah dan masyarakat. Good governance memiliki sistem aturan, proses, dan perilaku yang mempengaruhi bagaimana kekuasaan dijalankan pada setiap tingkatan pemerintah yang biak, yaitu pemerintah desa. Indikator good governance yang diterapkan dalam pemerintahan desa meliputi transparansi, akuntabilitas publik serta value of money.

Segala kegiatan pemerintah tentunya harus berlandaskan pada prinsip-prinsip good governance yang berlaku, terutama pada laporan keuangan desa yang secara transparan terhadap publik tentu akan meningkatan kepercayaan masyarakat terhadap kinerja pemerintah desa. Segala kegiatan pemerintahan yang baik tentunya akan meningkatkan kinerja pemerintah desa.

\section{LANDASAN TEORI DAN PENGEMBANGAN HIPOTESIS}

\section{Teori Keagenan}

Menurut Einshardt, 1989 dalam(Agus, Putra, Pande, \& Putra, 2018)teori keagenan bisa dipandang sebagai model kontraktual antara dua pihak atau lebih dimana salah satu pihak dpat disebut sebagai agen, sedangkan satu pihaknya lagi disebut dengan prinsipal. Agen yaitu orang yang telah diberi kekuasaan oleh prinsipal. Prinsipal yaitu pemilik perusahaan. Jika kedua belah pihak tersebut memiliki tujuan yang sama, tentunya akan meningkatkan nilai dari organisasinya. Pencapaian suatu tujuan dan kinerja organisasi tidak akan terlepas dari suatu kinerja manajemen organisasi. 


\title{
Journal Competency of Business
}

\author{
2020 Vol 4. No II
}

\section{Stewardship Theory}

Menurut Donaldson dalam (Andika, 2017)asumsi dari teori ini yaitu berdasarkan sifat-sifat manusia yang dapat dipercaya, memiliki integritas, bertanggung jawab atas setiap tindakannya, serta jujur kepada semua pihak. Stewardship theory menggambarkan bahwa manajemen dapat berperilaku baik demikepentingan banyak pihak, sehingga tercipta hubungan antara kepuasan organisasi dan kesusksesannya. Implikasi teori ini dalam penelitian ini yaitu untuk mendeskripsikan eksistensi pemerintah desa sebagai organisasi sektor publik yang bisa dipercaya, menampung aspirasi masyarakatnya, memberikan pelayanan yang baik, dan dapat mempertanggungjawabkan apa yang diamanahkan kepadanya.

\section{Hubungan Sistem Keuangan Desa terhadap Good Governance}

Tujuan diterapkannya sistem keuangan desa yaitu untuk memudahkan dalam kegiatan pelaporan keuangan. Selain itu juga untuk menata tata kelola keuangan desa secara optimal serta sebagai alat kendali/tolak ukur dalam segala proses pengelolaan keuangan desa. Jusuf Wanandi dalam (Bahrudin, 2015)mengemukakan makna Good Governance adalah kekuasaan yang didasarkan pada peraturan perundang-undangan yang berlaku, segala kebijakan yang diambil secara transparan, dan dapat dipertanggungjawabkan (akuntabel) kepada masyarakat. Oleh karena itu, dengan adanya sistem keuangan desa yang digunakan untuk kegiatan tata kelola kegiatan pelaporan keuangan desa yang berdasarkan prinsip-prinsip good governance tentunya tidak akan keluar dari koridor perundang-undangan yang berlaku.

H1 : Sistem keuangan desa berpengaruh positif terhadap good governance

\section{Hubungan Good Governance terhadap Kinerja Pemerintah Desa}

Good governance merupakan tata kelola pemerintahan yang baik yang diterapkan oleh pemerintah berupa sistem yang mengatur dan mengontrol segala kegiatan demi terwujudnya pemerintahan yang efektif dan efisien, sehat dan bermutu, serta memberikan dampak yang baik bagi pemerintah dan masyarakat. Mardiasmo (2009) dalam (Triseptya \& Hatta Harmiati, 2019) menyatakan bahwa kinerja atau performance merupakan deskripsi tentang pencapaian hasil kerja suatu kegiatan atau kebijakan tertentu dalam rangka mencapai tuuan, visi, dan misi organisasi tempat bekerja yang segalanya di desain dalam rencana strategis organisasi. Good governance tentunya dijadikan landasan dalam melaksankan kegiatan pemerintahan. Kinerja pemerintah desa yang baik tentunya tidak lepas dari pemahaman prinsipprinsip good governance. Pegawai yang mempunyai pemahaman good governance secara tepat dan benar, tentu akan berpengaruh terhadap profesionalitas kerja dalam berkarya, dengan orintasi kinerja yang tinggi untuk mencapai tujuan akhir dari suatu organisasi. Pemahaman good governance yang kuat tentu menimbulkan dampak positif bagi kinerja pegawai serta kinerja pemerintah desa.

$\mathrm{H} 2$ : Good governance berpengaruh positif terhadap kinerja pemerintah desa 


\section{Journal Competency of Business}

\section{Vol 4. No II}

\section{Hubungan Sistem Keuangan Desa terhadap Kinerja Pemerintah Desa}

Sistem keuangan desa merupakan aplikasi yang dikembangkan oleh Badan Pengawasan Keuangan dan Pembangunan (PKP) dalam rangka meningkatkan kualitas tata kelola keuangan desa. Sinungan (2001:11) dalam(Rolando, 2015), kinerja atau performance yaitu hasil kerja yang sifatnya konkret, dapat diamati, dan juga dapat diukur. Dengan diterapkannya sistem keuangan desa (siskeudes) diharapkan dapat membantu kinerja aparat desa itu sendiri dalam segala kegiatan pengelolaan laporan keuangan desa. Sehingga dengan adanya sistem keuangan desa yang akuntabel serta transparan dapat meningkatkan kinerja pemerintah desa dalam mutu pelayanan sektor publik kepada masyarakat, dan akan meningkatkan kepercayaan masyarakat terhadap pemerintah.

H3 : Sistem keuangan desa berpengaruh positif terhadap kinerja pemerintah desa

\section{Hubungan Sistem Keuangan Desa terhadap Kinerja Pmerintah Desa dengan Good Governance Sebagai Variabel Intervening}

Aplikasi sistem keuangan desa yang dilaksanakan dalam rangka pengelolaan anggaran dana desa yang dimuat dalam laporan keuangan yang dilakukan oleh pegawai desa tentu harus sesuai dengan peraturan perundang-undangan yang berlaku. Aplikasi sistem keuangan desa diharapkan untuk mempermudah kinerja pegawai desa dalam pengelolaan keuangan desa dengan berdasarkan prinsip-prinsip good governance yang berlaku sehingga tidak keluar dari koridor peraturan yang berlaku, karena good governance merupakan landasan kegiatan pemerintahan. Segala kegiatan pemerintahan terutama dalam pelaporan keuangan yang transparan dan akuntabel sesuai dengan prinsip good governance yang berlaku tentu akan memberikan dampak positif terhadap kinerja pemerintah desa.

H4 : Sistem keuangan desa berpengaruh positif terhadap kinerja pemerintah desa dengan good governance sebagai variabel intervening 


\section{Journal Competency of Business}

\section{Vol 4. No II}

\section{METODOLOGI PENELITIAN}

\section{Populasi, Sampel, Dan Teknik Pengambilan Sampel}

Populasi yang digunakan dalam penelitian ini adalah seluruh desa yang ada di Kabupaten Kulon Progo. Sampel yang digunakan yaitu seluruh desa yang ada di Kecamatan Panjatan yang terdiri dari 11 desa. Teknik pengambilan sampel dengan cara metode Purposive Sampling.

\section{Definisi Operasional}

\section{Sistem Keuangan Desa}

Sistem keuangan desa merupakan aplikasi yang dikembangkan oleh BPKP dalam rangka meningkatkan kualitas tata kelola keuangan desa. Indikator yang digunakan yaitu: kualitas SDM, faktor sosial, kualitas sistem, kualitas informasi, persepsi kegunaan, persepsi kemudahan penggunaan, dan minat menggunakan. Pada penelitian ini, variabel sistem keuangan desa diukur menggunakan skala likert, dengan 5 (lima) kriteria penilaian mulai dari : Sangat Setuju (SS), Setuju (S), Netral (N), Tidak Setuju (TS), dan Sangat Tidak Setuju (STS).

\section{Good Governance}

Variabel intervening adalah variabel yang secara teoritis mempengaruhi hubungan antara variabel independen dengan variabel dependen menjadi tidak langsung dan tidak dapat diamati dan diukur. Menurut World Bank mendefinisikan good governance sebagai suatu bentuk penyelenggaraan pembangunan yang solid dan bertanggung jawab yang sejalan dengan prinsip demokrasi dan pasar yang efisien, penghindaran salah alokasi dana investasi, dan pencegahan korupsi baik secara fisik maupun administratif, menjalankan disiplin anggaran serta penciptaan legal and political framework bagi tumbuhnya aktivitas usaha (Mardiasmo, 2009) dalam (Rahman, 2016). Indikator yang digunakan yaitu: transparansi, akuntabilitas, dan value of money.

Pada penelitian ini variabel good governance diukur menggunakan skala likert dengan 5 )lima) kriteria penilaian mulai dari : Sangat Setuju (SS), Setuju (S), Netral (N), Tidak Setuju (TS), dan Sangat Tidak Setuju (STS). Berikut ringkasan definisi operasional good governance : 


\section{Journal Competency of Business}

\section{Vol 4. No II}

\section{Kinerja Pemerintah Desa}

Mardiasmo (2009) dalam (Triseptya \& Hatta Harmiati, 2019) menyatakan bahwa kinerja atau performance merupakan deskripsi tentang pencapaian hasil kerja suatu kegiatan atau kebijakan tertentu dalam rangka mencapai tujuan, visi, dan misi organisasi tempat bekerja yang segalanya di desain dalam rencana strategis organisasi. Indikator yang digunakan yaitu: pelatihan, motivasi, dan kinerja.

Pada penelitian ini variabel kinerja pemerintah desa diukur menggunakan skala likert dengan 5 (lima) kriteria penilaian mulai dari : Sangat Setuju (SS), Setuju (S), Netral (N), Tidak Setuju (TS), dan Sangat Tidak Setuju (STS). Berikut ringkasan definisi operasional kinerja pemerintah desa :

\section{METODE ANALISIS DATA}

\section{Analisis Deskriptif}

Analisis deskriptif digunakan untuk menganisa data yang diperoleh dari responden melalui angket yang telah diisi oleh responden selama penelitian berlangsung yang kemudian akan disajikan dalam bentuk deskripsi data dari masingmasing variabel. Dalam analisis deskriptif disajikan nilai maksimum, nilai minimum, mean, dan standar deviasi.

\section{Uji Asumsi Klasik}

\section{Uji Normalitas}

Uji normalitas digunakan untuk menguji apakah dalam model regresi terdapat distribusi normal antar variabel terikat dan variabel bebas. Apabila distribusi data normal atau mendekati normal berarti model regresi baik. Pengujian untuk menentukan data terdistribusi normal atau tidak, digunakan cara uji statistik non parametrik. Uji statistik non parametrik yang digunakan adalah Uji One-Sample Kolmogorov-Smirnov (I-Sample $K-S$ ). Apabila hasil nilai probabilitas menunjukkan signifikansi diatas 0,05 , maka variabel terdistribusi normal.

\section{Uji Multikolinieritas}

Uji multikolinieritas digunakan untuk mengetahui ada tidaknya korelasi yang tinggi antara variabel independen dalam model regresi. Multikolinieritas dalam model regresi dapat dilihat pada nilai tolerance dan VIF. Jika nilai VIF tidak lebih dari 10 dan nilai tolerance tidak kurang dari 0,1 , maka dikatakan terbebas dari multikolinieritas.

\section{Uji Heterokedastisitas}

Uji heterokedastisitas digunakan untuk menguji apakah dalam model regresi terdapat perbedaan variansi residu dari kasus pengamatan satu ke pengamatan yang lain. 


\title{
Journal Competency of Business
}

\author{
2020 Vol 4. No II
}

Model regresi dikatakan baik apabila homokedastisitas atau tidak terjadi heterokedastisitas. Homokedastisitas yaitu apabila variance dari residual pengamatan satu ke pengamatan lain tetap. Jika berbeda, disebut heterokedastisitas. Uji heterokedastisitas dilakukan dengan menggunakan uji glejser. Menurut Gujarati dalam Ghozali (2011:142) dalam uji glejser dilakukan untuk meregres nilai absolute residual terhadap variabel independen. Untuk menentukan ada tidak nya heterokedastisitas yaitu dengan melihat nilai signifikansi yang dihasilkan iji regresi tersebut. Jika nilai signifikansi yang dihasilkan lebih dari 0,05 , maka tidak terjadi heterokedastisitas. Sebaliknya jika nilai signifikansi kurang dari 0,05 makan akan terjadi heterokedastisitas.

\section{HASIL DAN PEMBAHASAN}

\section{Analisis Deskriptif}

\section{Tabel 1}

Hasil Analisis Deskriptif

\begin{tabular}{lcrrrr}
\hline \multicolumn{5}{c}{ Descriptive Statistics } \\
\hline \multirow{2}{*}{ Siskeudes } & N & Minimum & Maximum & Mean & Std. Deviation \\
GG & 50 & 51.00 & 95.00 & 73.7400 & 8.58525 \\
KPD & 50 & 54.00 & 85.00 & 66.4000 & 6.15116 \\
\hline $\begin{array}{l}\text { Valid N } \\
\text { (listwise) }\end{array}$ & 50 & 55.00 & 80.00 & 66.8800 & 5.84018 \\
\hline
\end{tabular}

Berdasarkan tabel diatas variabel Sistem Keuangan Desa memiliki skor tertinggi 95.00, skor terendah 51.00, skor rata-rata 73,7400 dan Std. Deviation 8,58525. Data Good Governance memiliki skor tertinggi 85.00, skor terendah 54.00, skor rata-rata 66.4000, dan Std.Deviation 6.15116. Data Kinerja Pemerintah Desa memiliki skor tertinggi 80.00 , skor terendah 55.00, skor rata-rata 66.8800, dan Std. Deviation 5.84018. 


\section{Journal Competency of Business}

\section{Vol 4. No II}

\section{Uji Asumsi Klasik}

\section{Uji Normalitas}

Tabel 2

Hasil Uji Normalitas

\begin{tabular}{llr}
\hline \multicolumn{2}{c}{ One-Sample Kolmogorov-Smirnov Test } \\
\hline \multicolumn{2}{c}{ Unstandardized Residual } \\
\hline$N$ & & 50 \\
Normal Parameters ${ }^{a, b}$ & Mean &, 0000000 \\
& Std. Deviation & 5,36769251 \\
Most Extreme & Absolute &, 074 \\
Differences & Positive &, 074 \\
& Negative &,- 066 \\
Kolmogorov-Smirnov Z &, 521 \\
Asymp. Sig. (2-tailed) &, 949 \\
\hline a. Test distribution is Normal. \\
b. Calculated from data. \\
\hline
\end{tabular}

Berdasarkan hasil pengujian yang ditunjukkan pada tabel diatas menunjukkan bahwa nilai Asymp. Sig > 0,05 atau 0,949 maka distribusi datanya dapat dikatakan normal.

\section{Uji Multikolinieritas}

Tabel 3

Hasil Uji Multikolinieritas

Coefficients $^{\mathbf{a}}$

\begin{tabular}{|c|c|c|}
\hline \multicolumn{3}{|c|}{ Coefficients $^{\mathrm{a}}$} \\
\hline Model & $\begin{array}{cc}\text { Unstandardized } & \text { Standardized } \\
\text { Coefficients } & \text { Coefficients }\end{array}$ & $\begin{array}{l}\text { Collinearity } \\
\text { Statistics }\end{array}$ \\
\hline
\end{tabular}

\begin{tabular}{|c|c|c|c|c|c|c|c|c|}
\hline & & B & Error & Beta & $\mathrm{t}$ & Sig. & Tolerance & VIF \\
\hline 1 & (Constant) & 41,313 & 9,173 & & 4,504 &, 000 & & \\
\hline & $\mathrm{Z}$ & ,360 & , 142 & ,368 & 2,537 & ,015 & ,857 & 1,167 \\
\hline & $X$ & ,041 & ,099 & ,060 & ,412 & 682, & ,857 & 1,167 \\
\hline
\end{tabular}

a. Dependent Variable: $Y$

Berdasarkan tabel 6 diatas dapat dilihat semua variabel independen memperoleh nilai tolerance 0,10 dan VIF, sehingga dapat disimpulkan bahwa semua variabel independen terbebas dari gejala multikolinieritas dan analisis data dapat dilanjutkan. 


\section{Journal Competency of Business}

\section{Vol 4. No II}

\section{Uji Heterokedastisitas}

Tabel 4

Uji Heterokedastisitas

\begin{tabular}{|c|c|c|c|c|c|}
\hline \multicolumn{6}{|c|}{ Coefficients ${ }^{a}$} \\
\hline \multirow[t]{2}{*}{ Model } & \multicolumn{2}{|c|}{$\begin{array}{c}\text { Unstandardized } \\
\text { Coefficients }\end{array}$} & \multirow{2}{*}{$\begin{array}{c}\begin{array}{c}\text { Standardized } \\
\text { Coefficients }\end{array} \\
\text { Beta }\end{array}$} & \multirow[b]{2}{*}{$\mathrm{t}$} & \multirow[b]{2}{*}{ Sig. } \\
\hline & B & $\begin{array}{l}\text { Std. } \\
\text { Error }\end{array}$ & & & \\
\hline 1 (Constant) & 2,227 & 5,158 & & ,432 & ,668 \\
\hline $\begin{array}{l}\text { X (Sistem Keuangan } \\
\text { Desa) }\end{array}$ & ,003 &, 056 & ,008 &, 051 & ,960 \\
\hline$Z$ (Good Governance) & ,031 & ,080 & ,062 & ,391 & ,698 \\
\hline
\end{tabular}

a. Dependent Variable: Abs_ut

Berdasarkan hasil uji heterokedastisitas melalui uji glejser dapat diketahui bahwa nilai signifikansin setiap variabel independen berada diatas atau lebih tinggi dibandingkan nilai signifikansi yang digunakan yaitu 0,05 . Oleh karena itu, dapat disimpulkan bahwa tidak terjadi heterokedastisitas pada variabel independen yang digunakan pada penelitian ini.

\section{Uji Hipotesis}

\section{Hasil Uji Validitas}

Semua hasil uji validitas variabel sistem keuangan desa, good governance, dan kinerja pemerintah desa menunjukkan hasil yang valid semua serta signifikan.

\section{Hasil Uji Reliabilitas}

Tabel 5

Hasil Uji Reliabilitas

\begin{tabular}{llll}
\hline No & Variabel & $\begin{array}{l}\text { Cronbach's } \\
\text { Alpha }\end{array}$ & Keterangan \\
\hline 1 & Sistem Keuangan Desa & 0,908 & Reliabel \\
2 & Kinerja Pemerintah Desa & 0,825 & Reliabel \\
3 & Good Governance & 0,813 & Reliabel
\end{tabular}

Sumber: Data primer diolah 2019

Dari tabel diatas menunjukkan jika variabel sistem keuangan desa, good governance, dan kinerja pemerintah desa menunjukkan hasil yang reliabel semua. 


\section{Journal Competency of Business}

\section{Vol 4. No II}

\section{Uji Simultan F (Uji F)}

Uji simultan digunakan untuk mengetahui apakah variabel independen yaitu sistem keuangan desa, good governance secara bersama-sama berpengaruh terhadap variabel dependen yaitu kinerja pemerintah desa. Berikut ini akan dipaparkan hasil uji F pada tabel dibawah ini :

Tabel 6

Hasil Uji Simultan F

\begin{tabular}{|c|c|c|c|c|c|}
\hline \multicolumn{6}{|c|}{ ANOVA $^{b}$} \\
\hline Model & & Sum of Squares & df & Mean Square & Sig. \\
\hline \multirow[t]{3}{*}{1} & Regression & 259,486 & 2 & 129,743 & $4,319,019^{a}$ \\
\hline & Residual & 1411,794 & 47 & 30,038 & \\
\hline & Total & 1671,280 & 49 & & \\
\hline
\end{tabular}

a. Predictors: (Constant), X, Z

b. Dependent Variable: $Y$

Berdasarkan hasil perhitungan secara simultan pada tabel diatas, pengaruh sistem keuangan desa, good governance terhadap kinerja pemerintah desa dengan nilai $\mathrm{F}$ hitung 4,319 $>\mathrm{F}$ tabel 3,195 dengan nilai sig. $<0,05$ atau 0,019 $<0,05$ sehingga dapat disimpulkan bahwa sistem keuangan desa, good governance secara simultan dinyatakan berpengaruh secara signifikansi terhadap kinerja pemerintah desa yang berati Ha diterima Ho ditolak.

\section{Pengaruh Sistem Keuangan Desa Terhadap Good Governance}

Pengaruh sistem keuangan desa terhadap good governance ditunjukkanoleh hasil output SPSS dibawah ini:

Tabel 7

Hasil Uji Hipotesis (Uji t)

\begin{tabular}{|c|c|c|c|c|c|}
\hline \multicolumn{6}{|c|}{ Coefficients $^{\mathrm{a}}$} \\
\hline \multirow{2}{*}{ Model } & $\begin{array}{r}\text { Unstanc } \\
\text { Coeffi }\end{array}$ & $\begin{array}{l}\text { rdized } \\
\text { ients }\end{array}$ & $\begin{array}{c}\text { Standardized } \\
\text { Coefficients }\end{array}$ & \multirow[t]{2}{*}{$\mathrm{t}$} & \multirow{2}{*}{ Sig. } \\
\hline & B & $\begin{array}{l}\text { Std. } \\
\text { Error }\end{array}$ & Beta & & \\
\hline \multirow{2}{*}{$\begin{array}{l}1 \text { (Constant) } \\
\mathrm{X}\end{array}$} & 42,914 & 6,974 & & 6,154 & , 000 \\
\hline &, 265 & ,094 & ,379 & 2,835 & ,007 \\
\hline
\end{tabular}

a. Dependent Variable: $\mathrm{Z}$ 


\title{
Journal Competency of Business
}

\author{
2020 Vol 4. No II
}

Tabel diatas menunjukkan hasil $\mathrm{t}$ hitung sebesar 2,835 dan nilai $\mathrm{t}$ tabel sebesar 2,010 dengan tingkat signifikansi sebesar 0,007 < 0,05. Hal ini menunjukkan sistem keuangan desa berpengaruh positif terhadap good governance.

\begin{tabular}{llrrrr}
\multicolumn{7}{c}{ Tabel 8 } \\
Hasil Uji R Square \\
Model Summary
\end{tabular}

a. Predictors: (Constant), $\mathrm{X}$

Hasil persamaan yang dapat disusun dari output tersebut adalah:

$\mathrm{Z}=\mathrm{p} 1 \mathrm{X}+\mathrm{e} 1$

$Z=0,379 X+\sqrt{1-0,143}$

$Z=0,379 X+0,925$

Besarnya koefisien regresi sistem keuangan desa terhadap good governance 0,379 satuan dengan besaran nilai variance yang tidak dapat dijelaskan oleh variabel sistem keuangan desa sebesar 0,925, maka variabel sistem keuangan desa berpengaruh positif terhadap good governance sesebsar 0,379. Hasil uji hipotesis terdapa pengaruh positif sistem keuangan desa terhadap good governance yang ditunjukkan oleh signifikansi 0,007 $<0,05$.

\section{Pengaruh Good Governance Terhadap Kinerja Pmerintah Desa}

Pengaruh good governance terhadap kinerja pemerintah desa ditunjukkan oleh hasil output SPSS dibawah ini

\section{Tabel 9}

\begin{tabular}{|c|c|c|c|c|c|c|}
\hline \multicolumn{7}{|c|}{ Hasil Uji Hipotesis (Uji t) } \\
\hline \multicolumn{7}{|c|}{ Coefficients $^{a}$} \\
\hline & \multirow{2}{*}{ Model } & \multicolumn{2}{|c|}{$\begin{array}{l}\text { Unstandardized } \\
\text { Coefficients }\end{array}$} & \multirow{2}{*}{$\begin{array}{c}\begin{array}{c}\text { Standardized } \\
\text { Coefficients }\end{array} \\
\text { Beta }\end{array}$} & \multirow{2}{*}{$\mathrm{t}$} & \multirow{2}{*}{ Sig. } \\
\hline & & B & $\begin{array}{l}\text { Std. } \\
\text { Error }\end{array}$ & & & \\
\hline \multirow[t]{3}{*}{1} & (Constant) & 41,313 & 9,173 & & 4,504 & 000 \\
\hline & $\mathrm{Z}$ & ,360 & 142 & ,368 & 2,537 & 015 \\
\hline & $X$ & 041 & 099 & 060 & 412 & 682 \\
\hline
\end{tabular}

Tabel diatas menunjukkan hasil t hitung sebesar 2,537 dan nilai t tabel sebesar 2,010 dengan tingkat signifikansi $0,015<0,05$. Hal ini membuktikan bahwa good 


\section{Journal Competency of Business}

\section{Vol 4. No II}

governance berpengaruh positif terhadap kinerja pemerintah desa.

Tabel 10

Hasil Uji R Square

\begin{tabular}{|c|c|c|c|c|}
\hline Model & $\mathrm{R}$ & $R$ Square & $\begin{array}{l}\text { Adjusted } R \\
\text { Square }\end{array}$ & $\begin{array}{l}\text { Std. Error of } \\
\text { the Estimate }\end{array}$ \\
\hline 1 &, $394^{\mathrm{a}}$ & ,155 & ,119 & 5,48071 \\
\hline
\end{tabular}

a. Predictors: (Constant), X (Sistem Keuangan Desa),Z (Good Governance)

Hasil persamaan yang dapat diperoleh dari output tersebut adalah:

$\mathrm{Y}=\mathrm{p} 2 \mathrm{Z}+\mathrm{p} 3 \mathrm{X}+\mathrm{e} 2$

$\mathrm{Y}=0,368 \mathrm{Z}+0,060 \mathrm{X}+$

$\mathrm{Y}=0,368 \mathrm{Z}+0,060 \mathrm{X}+0,919$

Besarnya koefisien regresi sederhana good governance terhadap kinerja pemerintah desa sebesar 0,368 satuan dengan besaran nilai variance yang tidak dapat dijelaskan oleh variabel good governance sebesar 0,919. Hasil uji hipotesis terdapat pengaruh positif good governance terhadap kinerja pemerintah desa yang ditunjukkan oleh signifikan 0,015 yang berada dibawah 0,05 .

\section{Pengaruh Sistem Keuangan Desa Terhadap Kinerja Pemerintah Desa}

Berdasarkan tabel 9 dapat dilihat bahwa sistem keuangan desa tidak berpengaruh pada kinerja pemerintah desa. Hal tersebut dibuktikan dengan nilai koefisien regresi sebesar 0,060, sementara t hitung 0,412 < t tabel sebesar 2,010 dengan nilai signifikansinya $>0,05$ atau $0,682>0,05$.

Hasil persamaan yang dapat diperoleh dari output tersebut adalah:

$\mathrm{Y}=\mathrm{p} 2 \mathrm{Z}+\mathrm{p} 3 \mathrm{X}+\mathrm{e} 2$

$\mathrm{Y}=0,368 \mathrm{Z}+0,060 \mathrm{X}+$

$\mathrm{Y}=0,368 \mathrm{Z}+0,060 \mathrm{X}+0,919$

Besarnya koefisien regresi sederhana sistem keuangan desa terhadap kinerja pemerintah desa sebesar 0,060 satuan dengan besaran nilai variance yang tidak dapat dijelaskan oleh variabel sistem keuangan desa sebesar 0,919. Hasil uji hipotesis menunjukkan bahwa sistem keuangan desa tidak berpengaruh terhadap kinerja pemerintah desa yang ditunjukkan oleh signifikan 0,682 yang berada di atas atau lebih dari 0,05 . 


\section{Journal Competency of Business}

\section{Vol 4. No II}

\section{Pengaruh Sistem Keuangan Desa Terhadap Kinerja Pemerintah Desa Melalui Good Governance Sebagai Variabel Intervening}

Besarnya pengaruh tidak langsung, yaitu antar variabel sistem keuangan desa terhadap kinerja pemerintah desa melalui Good Governance sebagai variabel intervening dapat dijelaskan dengan gambar path analisis yang disusun dari perolehan dua persamaan regresi sebelumnya yaitu:

$Z=0,379 X+0,925$

$Y=0,368 Z+0,060 X+0,919$

Hasil angka koefisien regresi tersebut dapat digunakan untuk mengisi gambar path dibawah ini.

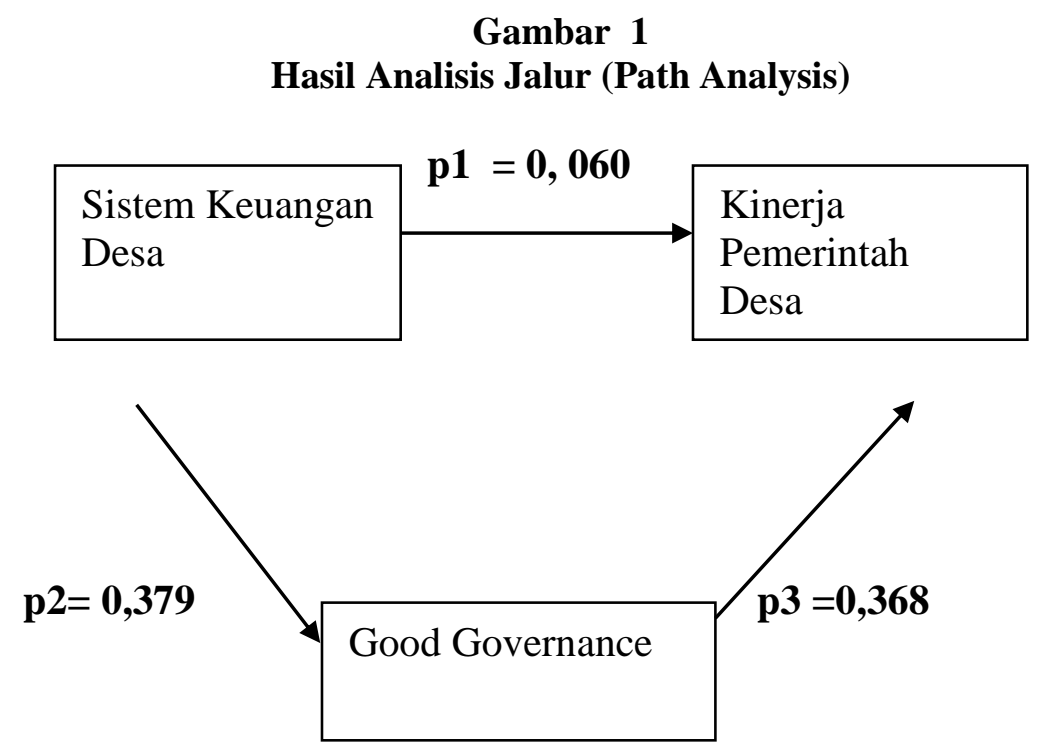

P1 = Koefisien Regresi Sistem Keuangan Desa Terhadap Kinerja Pemerintah Desa, jalur/ path $1=0,060$

P2 = Koefisien Regresi Sistem Keuangan Desa Terhadap Good Governance, jalur /path $2=0,379$

P3 = Koefisien Regresi Good Governance Terhadap Kinerja Pemerintah Desa, jalur / path $=0,368$

Untuk mengetahui apakah sistem keuangan desa berpengaruh terhadap kinerja pemerintah desa dengan good governance sebagai variabel intervening adalah sebagai berikut : 


\section{Journal Competency of Business}

\section{Vol 4. No II}

Pengaruh langsung SKD ke KPD

$=\mathrm{p} 1=0,060$

Pengaruh tidak langsung SKD ke GG ke KPD

$=\mathrm{p} 2 \times \mathrm{p} 3$

$=0,379 \times 0,368$

$=0,139472$

Berdasarkan perhitungan diatas, pengaruh tidak langsung SKD terhadap KPD dengan GG sebagai variabel intervening sebesar 0,139472 lebih besar daripada pengaruh langsung SKD terhadap KPD, sehingga GG memperkuat pengaruh SKD terhadap KPD.

\section{PEMBAHASAN}

\section{Sistem Keuangan Desa Berpengaruh Terhadap Good Governance}

Nilai t hitung untuk sistem keuangan desa adalah 2,835 lebih besar dari nilai t tabel sebesar 2,010 dengan nilai signifikansinya $0,007<0,05$. Ini menunjukkan bahwa Sistem Keuangan Desa berpengaruh positif terhadap Good Governance.

Jusuf Wanandi (1998) dalam (Bahrudin, 2015) mengemukakan Good Governance adalah kekuasaan yang didasarkan pada peraturan perundang-undangan yang berlaku, segala kebijakan yang diambil secara transparan, dan dapat dipertanggung jawabkan (akuntabel) kepada masyarakat. Hal ini menunjukkan bahwa Good Governance memiliki kekuasaan dalam pengendalian tata kelola keuangan yang bisa dipertanggungjawabkan.

\section{Good Governance Berpengaruh Terhadap Kinerja Pemerintah Desa}

Nilai t hitung pada good governance sebesar 2,537 yang lebih besar dari nilai $t$ tabel sebesar 2,010 dengan tingkat signifikansinya $0,015<0,05$. Ini menunjukkan bahwa good governance berpengaruh positif terhadap Kinerja Pemerintah Desa.

Menurut (Azlina \& Amelia, 2015) bahwa pelaksanaan good governance pada pemerintahan dilaksanakan dengan baik sesuai peraturan perundang-undangan yang berlaku, maka kinerja pemerintah desa juga akan semakin meningkat. Dengan demikian good governance berpengaruh positif terhadap kinerja pemerintah desa.

\section{Sistem Keuangan Desa Berpengaruh Terhadap Kinerja Pemerintah Desa}

Nilai t hitung pada Sistem Keuangan Desa sebesar 0,412 yang lebih kecil dari nilai $t$ tabel sebesar 2,010 dengan tingkat signifikansinya 0,682 >0,05. Hal ini menunjukkan bahwa Sistem Keuangan Desa tidak berpengaruh terhadap kinerja Pemerintah Desa.

Menurut (Abdullah \& Samad, 2019) keterbatasan sumber daya manusia dalam menjalankan sistem keuangan desa dapat dilakukan dengan cara memberikan 


\section{Journal Competency of Business}

\section{Vol 4. No II}

pendidikan dan pelatihan secara teratur, melakukan koordinasi dengan para pendamping desa, atau mengundang staf BPKP untuk meberikan motivasi bagi para pegawai perangkat desa dalam meberikan materi sistem keuangan desa, serta menyediakan sarana dan prasarana yang akan digunakan untuk meningkatkan sumber daya manusianya.

Dari paparan diatas dapat yang hipotesis menyatakan sistem keuangan desa berpengaruh terhadap kinerja pemerintah desa ternyata tidak terbukti berpengaruh.

\section{Sistem Keuangan Desa Berpengaruh Terhadap Kinerja Pemerintah Desa Dengan Good Governance Sebagai Variabel Intervening}

Nilai t hitung Sistem Keuangan Desa sebesar 2,1340 yang lebih besar dari nilai $\mathrm{t}$ tabel sebesar 2,010 dengan tingkat signifikansi 5\% dan besarnya koefisien mediasi (pengaruh tak langsung) 0,139472. Serta besarnya pengaruh tidak langsung yaitu 0,139472. Hal ini menunjukkan bahwa terdapat pengaruh tidak langsung Sistem Keuangan Desa terhadap Kinerja Pemerintah Desa melalui Good Governance sebagai variabel intervening.

Menurut(Sulina, Wahyuni, \& Kurniawan, 2017) manfaat dari penggunaan sistem keuangan desa dirasa cukup signifikan bagi para pegawai desa. Dengan adanya sistem keuangan desa tersebut telah membantu kinerja pemerintah desa, dimana pekerjaan lebih terencana dan terarah sesuai dengan ketentuan yang telah ditentukan. Dalam penggunaan aplikasi sitem keuangan desa tetap harus berlandaskan prinsipprinsip good governance seperti transparansi, akuntabel, dan value of money sehingga dapat dipertanggungjawabkan kepada publik dan sumber daya manusia tentu akan semakin baik yang berdampak positif terhadap kinerja pemerintah desa. Hal ini menunjukkan bahwa sistem keuangan desa berpengaruh terhadap kinerja pemerintah desa dengan good governance sebagai variabel intervening terbukti adanya.

\section{KESIMPULAN}

Penelitian ini menguji sistem keuangan desa terhadap kinerja pemerintah desa dengan good governance sebagai variabel intervening dengan menggunakan analisis jalur (Path Analys). Berdasarkan penelitian dapat disimpulkan sebagai berikut :

a. Pengaruh sistem keuangan desa terhadap good governance. Realisasi anggaran yang dikelola dalam satu aplikasi sistem keuangan desa harus selalu berpacu pada prinsip-prinsip good governance yang ditetapkan pada pemerintah desa demi kepentingan masyarakat publik dan bersama. Pelaporan keuangan dengan menggunakan aplikasi sistem keuangan desa di sektor publik berupa laporan realisasi anggaran sebagai bentuk dari pertanggungjawaban pemerintah khususnya bagi anggota bidang keuangan. Suatu organisasi dapat dikatakan berjalan sesuai dengan prinsip good governance apabila pengelolaan keuangan yang sudah berbentuk aplikasi sistem keuangan desa telah berjalan sesuai dengan standar yang berlaku dan menghasilkan pelaporan keuangan yang andal dan relevan. Hasil ini sejalan dengan penelitian sebelumnya yang menyatakan pengelolaan keuangan daerah berpengaruh positif terhadap good governance(Ristanti, Sinarwati, \& Sujana, 2014)yang menyatakan bahwa suatu 


\section{Journal Competency of Business}

\section{Vol 4. No II}

organisasi dikatakn berjalan sesuai dengan prinsip good governance apabila pengelolaan keuangan telah berjalan sesuai dengan standar yang berlaku dan menghasilkan pelaporan yang andal dan relevan.

b. Pengaruh good governance terhadap kinerja pemerintah desa. Prinsip-prinsip good governance jika dijalankan sebagaimana mestinya tentu akan menjadikan kinerja pemerintah desa semakin membaik. Pegawai yang mempunyai pemahaman prinsip-prinsip good governance secara tepat dan benar tentunya akan berpengaruh terhadap profesionalitas kerja dalam berkarya dengan orientasi kerja yang tinggi untuk mencapai tujuan akhir dari suatu organisasi tersebut. Pemahaman prinsip-prinsip good governance yang baik tentu akan menimbulkan dampak positif dan kinerja dari pemerinath desa akan menjadi semakin baik. Hal ini juga didukung oleh penelitian sebelumnya (Azlina \& Amelia, 2015)yang menyatakan apabila pelaksanaan good governance pada pemerintah dilaksanakan dengan baik, maka kinerja pemerintah juga semakin meningkat.

c. Pengaruh sistem keuangan desa terhadap kinerja pemerintah desa. Setelah dilakukan penelitian ternyata hipotesis tidak terbukti adanya pengaruh, jadi sistem keuangan desa tidak berpengaruh terhadap kinerja pemerintah desa. Dalam hal ini penggunaan aplikasi sistem keuangan desa belum sepenuhnya bisa berjalan dengan baik dan lancar di setiap desa serta masih banyaknya pegawai desa terutama bendahara desa yang sudah tidak memungkinkan untuk menggunakan sebuah aplikasi karena beberapa faktor seperti faktor usia. Mereka lebih nyaman menggunakan laporan keuangan secara manual daripada menggunakan sebuah aplikasi, karena para pegawai merasa tidak mampu dalam mengoperasikan aplikasi tersebut. Walaupun desa-desa sudah mengangkat tenaga teknis khusus operator aplikasi siskeudes, namun hasilnya masih sama tidak meningkatkan kinerja pemerintah desa itu sendiri. Kurangnya sosialisi dan pelatihan dalam penggunaan aplikasi siskeudes menjadi faktor utama sehingga tidak menunjukkan hasil positif dalam meningkatkan kinerja pemerintah desa. Penelitian ini tidak mendukung dari penelitian sebelumnya yang mengatakan sistem keuangan desa berpengaruh terhadap kinerja pemerintah desa (Sulina et al., 2017)yang menyatakan peranan sistem keuangan desa dengan proses penginputan sekali sesuai dengan transaksi yang ada, dapat menghasilkan output yang sebenarnya, serta para pegawai merasakan terbantu akan adanya aplikasi sistem keuangan desa.

d. Pengaruh Sistem Keuangan Desa terhadap kinerja pemerintah desa melalui good governance sebagai variabel intervening. Semakin tinggi pemahaman pegawai desa terhadap prinsip-prinsip good governance yang menjadikan landasan segala pekerjaan para pegawai seperti halnya dalam penggunaan aplikasi sistem keuangan desa yang berdasarkan prinsip-prinsip good governance yang diterapkan tentunya akan bisa meningkatkan segala kinerja pegawai dalam segala pelayanan publik yang berhubungan dengan masyarakat. Jika salah satu prinsip good governance seperti transparansi diterapkan dalam pemerintah desa dalam hal laporan keuangan yang dikelola dalam sebuah aplikasi sistem keuangan desa yang bisa ditunjukkan kepada publik, sehingga masyarakat bisa menilai baik tidaknya kinerja pemerintah desa. Penggunaan aplikasi sistem keuangan desa 


\title{
Journal Competency of Business
}

\author{
2020 Vol 4. No II
}

yang berlandaskan prinsip good governance akan meningkatkan segala kinerja pemerintah desa. Hal ini juga mendukung dari penelitian sebelumnya (Putra, 2017)yang mengatakan prinsip good governance seperti transparansi yang menjamin akses atau kebebasan bagi setiap orang untuk memperoleh informasi tentang penyelanggaraan pemerintahan.

\section{SARAN}

Untuk peneliti selanjutnya diharapakan dapat menambahkan variabel yang mempengaruhi kinerja pemerintah desa seperti sistem pengendalian internal dan laporan keuangan. Untuk pengambilan data diharapkan peneliti selanjutnya dapat menambahkan metode wawancara sehingga data yang diharapkan dapat menggambarkan keadaan yang sebenarnya.

\section{REFERENSI}

Abdullah, M., \& Samad, A. (2019). Pengaruh Sistem Informasi Keuangan Desa (Siskeudes) Terhadap Kinerja Kepala Desa (Studi Kasus Desa Takoka, Kecamatan Gane Barat Utara, Kabupaten Halmahera Selatan). IJIS-Indonesia Journal on Information System, 2. https://doi.org/10.1021/jp5128578

Agus, I. G., Putra, S., Pande, I. M., \& Putra, D. (2018). E-Jurnal Akuntansi Universitas Udayana Pengaruh Good Governance dan Sistem Pengendalian Intern Pemerintah Pada Kinerja Pemerintah Daerah Fakultas Ekonomi dan Bisnis Universitas Udayana ( Unud ), Bali , Indonesia email: agussudiarsana95@gmail.com / Telp: E-Jurnal Akuntansi Universitas Udayana, 25, 1720-1743.

Andika, D. (2017). Persepsi Aparatur Desa Mengenai Pelatihan Motivasi Dan Pengelolaan Alokasi Dana Desa Terhadap Kinerja Pemerintah Desa (Studi Survei Pada Kecamatan Mojotengah Kabupaten Wonosobo). https://doi.org/10.1017/CBO9781107415324.004

Azlina, N., \& Amelia, I. (2015). Pengaruh Good Governance Dan Pengendalian Intern Terhadap Kinerja Pemerintah Kabupaten Pelalawan. Jurnal Akuntansi Universitas Jember, 12(2), 32. https://doi.org/10.19184/jauj.v12i2.1409

Bahrudin, A. (2015). Pola Hubungan Pemerintahan Desa Dan Parlemen Desa Menuju Good Governance Pendahuluan Good Governance Dan Relevansinya Dalam Pembaharuan Pemerintahan Desa.

Putra, H. S. (2017). Tata Kelola Pemerintahan Desa Dalam Mewujudkan Good Governance di Desa Kalibelo Kabupaten Kediri. Jurnal Politik Muda, 6(2), 110-119. Retrieved from http://journal.unair.ac.id/download-fullpapers-jpmeebaec089dfull.pdf

Rahman, K. G. (2016). Pengaruh Penerapan Good Governance dan Pengendalian Internal Terhadap Kinerja Pengelolaan Keuangan Pemerintah Daerah di Kota Makassar.

Ristanti, N. M. A., Sinarwati, N. K., \& Sujana, E. (2014). Pengaruh Sistem Pengendalian Intern, Pengelolaan Keuangan Daerah Dan Komitmen Organisasi Terhadap Penerapan Good Governance. Jurnal Akuntansi, 2(1), 1-11. 


\section{Journal Competency of Business}

\section{Vol 4. No II}

Rolando, T. (2015). KINERJA PEMERINTAH DESA DALAM PELAYANAN ADMINISTRASI KEPENDUDUKAN DI DESA POOPO BARAT KECAMATAN RANOYAPO KABUPATEN MINAHASA SELATAN.

Sulina, I. G., Wahyuni, M., \& Kurniawan, P. (2017). Peranan Sistem Keuangan Desa (SISKEUDES) Terhadap Kinerja Pemerintah Desa ( Studi Kasus di Desa Kaba-kaba , Kecamatan Kediri, Kabupaten Tabanan ) e-Journal S1 Ak Universitas Pendidikan Ganesha. Jurnal Akuntansi, 1(2).

Triseptya, G. N., \& Hatta Harmiati. (2019). Pengaruh Kompetensi Terhadap Kinerja Bendahara Desa (Studi Kasus Pada Desa Di Kabupaten Pinrang), 2(1). 